Seloka: Jurnal Pendidikan Bahasa dan Sastra Indonesia

9 (2) (2020): 118-128

UNNES

http://journal.unnes.ac.id/sju/index.php/seloka

\title{
The Meaning of Tolaki, Minangkabau, and Timor Cultural Symbol in Three Nusantara Folklores: Oheo, Kaba Malin Deman, and Tujuh Bidadari
}

\author{
Hendrike Priventa ${ }^{\bowtie}$ Redyanto Noor
}

DOI : https://doi.org/10.15294/seloka.v9i2. 38695

Master of Literature Program, Faculty of Humanities, Diponegoro University, Indonesia

\begin{tabular}{l}
\hline Artikel Info \\
\hline History Article \\
Received: \\
5 March 2020 \\
Accepted: \\
11 June 2020 \\
Published \\
21 August 2020 \\
\hline Keywords: \\
Folklore; Cultural \\
Symbol; Tolaki; \\
Minangkabau; Timor
\end{tabular}

\begin{abstract}
Indonesian are less aware of the function of folklore in the modern era. When examined more deeply, folklore is a manifestation of local cultural values that are not widely known. This is the background for the research of this article which intends to introduce the uniqueness of the Nusantara folklore through an analysis of the eating of cultural symbols. The purpose of this research is to describe and introduce the meaning of cultural symbols in the Nusantara folklore. The method used is literature using semiotic theory. The results obtained in this study are as follows. 1) Folklore is part of a culture, therefore in the structure of folklore found cultural elements represented in the form of symbols. 2) Cultural symbols in folklore cannot be interpreted directly, with a semiotic and cultural approach symbols can be interpreted according to the cultural origin of the folklore. 3) Literature, culture, and art are three things that cannot be separated. Cultural symbols do not only show cultural elements but also provide a moral message and aesthetic side in reading literary works. 4) Folklore can become an identity in culture from that it can be drawn that cultural symbols can show the progress of civilization in a culture. 5) The three folklores of the archipelago that have been studied have their own characteristics. Oheo with the influence of the elements of marriage and social stratification, Kaba Malin Deman with a touch of matrilineality, and Tujuh Bidadari with the influence of religious elements.
\end{abstract}




\section{INTRODUCTION}

Culture has various definitions. However, the context of culture can never be separated from society. This shows that society and culture cannot be separated (Nahak, 2019). Related with literature, culture has unique product which is called folklore. (Hidayah, 2015) tells that Indonesia is a plural country. This is reflected in the existence of various folklores from Sabang to Merauke. Unfortunately, its existence began to fade because the assumption that folklore is ancient. If folklore studied deeply, based on (Jauhari, 2018), folklore is a place to inform the geography condition and cultural values of a specific community. Because folklore is fictitious, the existence of cultural values will be transformed into symbols.

Symbol and meaning are two of the characteristics of literary products. Beside functioning as the achievement of a purpose (hidden meaning), it is an element that beautifies a literary work. Symbols can function as a means of conveying subtle meanings (Inayati, 2016). Based on this, three Nusantara folklores related about marriage were chosen. Marriage is an object that is always interesting to study. The progress of times and social changes affect the tradition and meaning of marriage itself (Annisa, 2017), so the researchers found three Nusantara folklores that have similarities, namely Oheo from Southeast Sulawesi, Kaba Malin Deman from West Sumatra, and Tujuh Bidadari from East Nusa Tenggara.

The first story comes from the Tolaki culture, namely Oheo. Oheo is a folk tale that is quite interesting because it has a similar story with Jaka Tarub's folklore. Oheo himself is a central figure in the story who married a fairy named Anawaingguluri. Oheo found the sarungngguluri which is a kind of flying suit mask used by Anawaingguluri to fly. After forcing Oheo finally agreed to give the sarung-ngguluri but Anawaingguluri had to marry him. Finally Anawaingguluri made an agreement; later when they had children, Oheo was the one who had to poke his child. Presumably it was denied so that Anawaingguluri left Oheo. The Oheo is a representation of Tolaki culture from a form of inter-class marriage. Folklore cannot be separated from the cultural elements contained in the story. This shows that the folklore is a symbol of the existence of the cultural origin of the story.

The second story is Kaba Malin Deman; it comes from the Minangkabau which tells of a young child who is raised by a widow named Mandeh Rubiah. Malin Deman, who was curious about the sound behind the hut, finally peeked at the seven fairies taking a shower and then had the intention of taking a scarf from one of the angel's possessions. The angel then lived with Mandeh Rubiah until she married Malin Deman. It is the same with Oheo's story with Tolaki culture. The story of Kaba Malin Deman is a manifestation of the Minangkabu cultural identity which is represented through symbols.

The third story is Tujuh Bidadari which comes from the Belu (Tetun) which is part of the Timor culture. Tujuh Bidadari tells about a young prince who married the youngest daughter of the sun. The young prince, who was peeking at the seven fairies bathing in the pool, intended to take the youngest's wings. The wings were hidden by the fire. The two later married and had sons. One day, his son found his mother's wings, which made the youngest daughter return to the sun. The cultural symbol is shown when the young prince gets seven challenges from the king. Each challenge displays symbols related to Timor culture.

The three folklores that have been described above have similarities and differences. Significant differences are related to the symbols in the story. These symbols are closely related to the culture of the setting for each story. Of the three, only the story of Kaba Malin Deman whose son is with his mother and his male character lives with a widow. The difference can also be seen from the tools used by the female character to fly, namely the winged masks, scarves and wings.

Definition of culture comes from Koentjaraningrat (1990), tells that the meaning of culture is the whole way of life of society, which is divided into three categories, namely 
ideas, actions and results of action. Based on this categorization, Koentjaraningrat defines culture as "the whole system of ideas, actions, and human work in the context of community life which belongs to humans. In his Pengantar Ilmu Antropologi, Koentjaraningrat divides cultural elements into seven, namely: (1) language, (2) technology system, (3) livelihood system, (4) social organization, (5) knowledge system, (6) religion, and (7) arts. These elements are used as benchmarks in determining symbols in research. In order to better understand the cultural background, we will briefly explain the Tolaki, Minangkabau and Timor.

Descriptive explanation of Tolaki culture based on Tarimana (1993), The Tolaki are an ethnic group that inhabits the mainland areas of Kendari Regency, Kendari City and Kolaka Regency, namely two of the four districts in Southeast Sulawesi Province. Both are the former territories of the Konawe Kingdom and the Mekongga Kingdom respectively. In these two districts, there are 22 sub-districts, 210 villages. The other two districts are Buton Regency and Muna Regency. Tolaki both those who live in villages and live from traditional farming, as well as those who live in cities and live as employees or as businessmen, until now apparently still consider important in their culture a sacred central symbol called kalo.

Umar Junus (2007) tells on article about Minangkabau mengenai in Manusia dan Kebudayaan di Indonesia that writes of the area of origin Minagkabau culture is as wide as the province of West Sumatra which is reduced by the Mentawai islands. There are two regional divisions, namely darek (land) and pesisie (coastal) or rantau. The Minangkabau culture which is well known is the merantau and matrilineal lineages, namely the principle of descent arranged according to the maternal line. Each individual will see himself as the descendant of his mother and grandmother and above. This will become clear if we look again at the principle of the family above the lineage which means the passing of inheritance, where everyone will receive an inheritance from their mother's family. The principle of matrilineal descent also determines the sako heritage, namely the title.

The inhabitants of the island of Timor, both who lived in the territory of Indonesia and in the territory of the Timor Leste (Portuguese), consisted of several special ethnic groups which differed due to language and several elements in their customs and social systems. The middle part, and inhabit this area from the north to the South (Hidayah, 2015). In the beliefs of the ethnic groups in East Nusa Tenggara, the worship of ancestral spirits is a prominent element. In agricultural ceremonies and ceremonies around the life cycle, it is a manifestation of worshiping the moon and sun. Timor is a unique language. Through the language unit, it can show cultural meaning that is reflected in the customs of the Timor tribe on the island of Sumba. One of the cases has to do with the community's habit of obeying and respecting the (Pekuwali, 2020). One of the known rituals is Nitoni, which shows Timor culture which is open to outside cultures (Fallo, 2016).

Previous research on the three folklores discussed intertextuality with local culture. On research of (Hastuti, 2019) shows that Oheo is related with position of Tolaki woman. According on (Elfira, 2016) also exemine Kaba Malin Deman with result is about the empowerment of woman Minangnese as a leader. Altough, Tujuh Bidadari has not examinated. Based on The three cultural backgrounds show differences regarding lineage and religious systems. On this basic, the researcher is interested in revealing the novelty regarding the meaning of the symbols from the three folklores with different cultural backgrounds.

On of the purpose of the research that direct anout meaning of cultural symbol, so this research used semiotic theory. Ratna (2010) tells that etymologically, the term semiotics comes from the Greek word "semeion" which means "sign". A sign is defined as something which, on the basis of previously developed social conventions, can be considered to represent something else. Semiotic theory is a theory that 
analyzes signs. Literary works will be seen as signs. The search for signs in a literary work that are specialized in signs that enable the sign to have meaning. The signs are then interpreted according to the system, rules and conventions of society. Based on (Oktavhia, 2019), The semiotic function shows several codes, namely symbolic codes and cultural codes. Through a semiotic approach, symbols do not only determine denotative meanings but also connotative meanings.

In this regard, the semiotic approach to culture introduced by Pierce is very suitable for research. There are three related things, namely icons, indexes, and symbols. Pradopo (1999) explains more about the three, namely, "Icons are signs that indicate a natural or similar relationship between a marker and a marker, for example a horse image as a marker that marks a horse as its meaning. An index is a sign that shows a causal / causal relationship between a marker and a marker, for example, smoke marks a fire. The meaning of symbol based on Pierce in (Rokhmansyah, 2014) there are three stages, namely; (1) First Stage / Firstness, which is a sign / symbol recognized at the initial stage only in principle or the existence of the sign as it is without pointing to something else, the existence of potential possibilities; (2) Second stage / Secondness, namely when the sign / symbol is interpreted individually and; (3) The third stage / Thirdness is when the sign / symbol is interpreted permanently as a convention.

\section{METHOD}

The main purpose of this research is to describe the problems related to the meaning of cultural symbols so, the approach used in this study is a semiotic and cultural theory. The research is library study. To apply the semiotic theory in this study, use Peirce's triadic. This method explained by Nurgiyantoro (2010), that sign is called representamen when referring to object. In this case the object represents or replaces the sign. Signs can function when interpreted through the interpreter. From this process, the understanding of meaning can be known.

The work steps in this research are divided into the following stages.

1. Structural analysis of the three folklores of Nusantara of Oheo, Kaba Malin Deman, and Tujuh Bidadari using a simple narrative structure showing plot and conflict.

2. Significant analysis to provide a sign in relation to cause-effect (index) in the narrative.

3. Symbol analysis and symbolic meanings in the three Nusantara folklores of Oheo, Kaba Malin Deman, and Tujuh Bidadari

4. Comparative analysis of cultural symbols that are similar to one another. To make it easier to present the results of the discussion, tables are used.

\section{RESULTS AND DISCUSSION}

\section{Narrative Structure of Oheo}

The following describes the narrative structure of the Oheo originating from Tolaki.

(1) Oheo heard a commotion in the river and appeared seven angels from above the heaven who were going down to bath

(2) Oheo and Anawaingguluri enter a new life as husband and wife and have a baby

(3) Oheo broke the agreement and made Anawaingguluri return to heaven leaving Oheo and his son

(4) Oheo is confused about his son and finds Ue-Wai huddled round

(5) Oheo and Anawaingguluri successfully complete the challenge and return to earth to open fields

\section{Narrative Structure of Kaba Malin Deman}

The following describes the narrative structure of Kaba Malin Deman originating from Minangkabau.

(1) Malim Deman is an orphan and works on his mother's rice fields and fields

(2) Malin Deman saw seven angels bathing in the pool

(3) Malin Deman and the youngest daughter fell in love and then married and had a son named Sutan Duano 
(4) The youngest daughter finds her scarf at Mandeh Rubiah's house

(5) Malin Deman knew that his wife and children had left him and regretted his actions

\section{Narrative Structure of Tujuh Bidadari}

The following describes the narrative structure of Tujuh Bidadari originating from Timor.

(1) The sun was ruled by a king who had seven beautiful daughters and had beautiful, white, and clean wings

(2) The seven angels often visited the young prince's pond which was surrounded by flowers and lined with areca trees, betel trees, and coconut trees.
(3) The young prince offered his youngest daughter to live in the palace, live together and marry and have a son

(4) The prince and his son followed into the sun with the help of a rattan tree

(5) The young prince successfully completed the challenge and the Sun King threw a party for seven days and seven nights

\section{Signifier in Three Folklores of Nusantara}

This discussion includes the most dominant signs in the three Nusantara folklores which can be considered as the main signifier representing the entire contents of the three Nusantara folklores.

\section{Signifier in Oheo}

Table 1. Signifier in Oheo

\begin{tabular}{ll}
\hline Element of Culture & Symbol \\
\hline Language & Oheo \\
Technology System & Anawaingguluri \\
& Sarunnga-ngguluri \\
& Palako \\
Talam & Sugar cane plantation \\
Livelihood System & Agreement \\
Social Organization & Heaven \\
& Ue-Wai \\
& Baginda \\
Knowledge System & Fauna (parrot, pig, rat, sparrow, quails, \\
& measured bird, cat, and fireflies) \\
& Seeds (burulae, rice, corn kernel, and woto) \\
Religion & River \\
Arts & Seven \\
\hline
\end{tabular}




\section{Signifier in Kaba Malin Deman}

Table 2. Signifier in Kaba Malin Deman

\begin{tabular}{ll}
\hline Element of Cultural & Symbol \\
\hline Language & Malin Deman \\
& Mandeh Rubiah \\
& Sutan Duano \\
& Bujang Karim \\
Technology System & Shawl \\
Livelihood System & Rice and field \\
Social Organization & Widow \\
& Heaven \\
Knowledge System & Not Found \\
Religion & Seven \\
Arts & Not Found \\
\hline
\end{tabular}

\section{Signifier in Tujuh Bidadari}

Table 3. Signifier in Tujuh Bidadari

\begin{tabular}{ll}
\hline Element of Cultural & Symbol \\
\hline Language & Not Found \\
Technology System & Wing \\
\hline Livelihood System & Not Found \\
Social Organization & Palace \\
& Servant \\
Knowledge System & Species of plant (areca nut, betel, coconut tree, \\
& kusambi tree, rotan) \\
& Fauna (ant, lion, weasel, termite, and louse \\
& Dilafatu fruits \\
& Honey and coconut oil \\
Religion System & Sun \\
& Seven \\
& Genie \\
Arts & Giant \\
& Dance \\
& Party \\
\hline
\end{tabular}




\section{Meaning of Tolaki Cultural Symbol in Oheo}

Table 4. Meaning of Tolaki Cultural Symbol in Oheo

\begin{tabular}{llc}
\hline \multicolumn{1}{c}{ Symbol } & Meaning \\
\hline 1. & Oheo dan Anawaingguluri & Tolaki's identity \\
2. Sarunnga-ngguluri & Femininity \\
3. Cane sugar planting & Livelihood in Tolaki \\
4. Agreement & Marriage's commitment \\
& Social stratification \\
5. Heaven & Distance of social class \\
6. Ue-Wai & Attribute of social class \\
7. Baginda & \\
8. Fauna (parrot, pig, rat, sparrow, quails, & \\
measured bird, cat, and fireflies) & Usage of endemic fauna endemik \\
9. Seeds (burulae, rice, corn kernel, and woto) & Usage of Talaki's commodity \\
10. River & Usage of Talaki's commodity \\
& \\
11. Palako dan Talam & Geography condition \\
12. Seven & Wedding tradition \\
\hline
\end{tabular}

\section{Meaning of Minangkabau Cultural Symbol in Kaba Malin Deman}

Table 5. Meaning of Minangkabau Cultural Symbol in Kaba Malin Deman

\begin{tabular}{ll}
\hline Symbol & Meaning \\
\hline Malin Deman & Minang's identity \\
Mandeh Rubiah & \\
Sutan Duano & \\
Bujang Karim & \\
Selendang & Femininity \\
Sawah dan tanaman padi & Minang's livelihood \\
Janda & Matrilineality \\
Kayangan & Social stratification \\
Angka tujuh & Lucky number \\
\hline
\end{tabular}

Table 5 shows that the Minangkabau's cultural symbol can be seen from the naming of characters in the Kaba Malin Deman. The word malin refers to the leader, therefore the character Malin is shown as a man. The word Mandeh in Minang means mother, while Rubiah means a pious woman as shown by the character Mandeh Rubiah as a widow. The word bujang refers to a single man or slave while karim is taken from Arabic which means generous. Sutan is a title in the kinship of the Minangkabau community. 


\section{Meaning of Timor Cultural Symbol in Tujuh Bidadari}

Table 6. Meaning of Timor Cultural Symbol in Tujuh Bidadari

\begin{tabular}{llc}
\hline \multicolumn{1}{c}{ Symbol } & Meaning \\
\hline 1. Wing & Femininity \\
2. Palace & Social stratification \\
3. Servant & Social stratification \\
4. Species of plant (areca nut, betel, coconut & Usage of Timor's commodity \\
tree, kusambi tree, rotan) & \\
5. Fauna (ant, lion, weasel, termite, and louse & \\
6. Dilafatu fruits & Usage of Timor's endemic fauna \\
7. Honey and coconut oil & \\
& & \\
8. Sun & Usage of Timor's commodity \\
9. Genie & Source of live \\
10. Giant & Myth creatures \\
11. Seven & Strength \\
12. Dance & Angka baik \\
13. Party & Character of Timor society \\
\hline
\end{tabular}

Based on table 6 shows that the cultural symbols in the Tujuh Bidadari have almost similarities with of Oheo. This is shown from the narrative structure of the two which have in common. However, cultural symbols still represent the original culture, namely Timor. Its most striking symbol is the sun. Universally, the sun has the meaning of the source of life. From Timor culture, the sun is one of the gods in the religious system.

Cultural symbols in the form of dances and party are included in the art category, not shown in the other two stories. In this case it is not stated in writing the type of dance but for the feast it is shown in the story that the King of Sun threw a party to celebrate the return of the husband of his youngest child.

\section{Meaning of Cultural Symbol in Three Nusantara Folklores Symbol of Kinship and Lineages}

The three stories show two lineages, namely patrilineal and matrilineal. The story of Oheo and the Tujuh Bidadari has the same pattern, namely patrilineal, while Kaba Malin Deman has a matrilineal style. The symbol of matrilineality is shown by the figure of the widow, Mande Rubiah. The following is a quote that shows the matrilineal side of the story.
Di sekitar sawah milik ibu Malin Deman itu tinggal seorang janda tua. Mandeh Rubiah namanya. Malin Deman sangat akrab dengan janda tua itu. Bahkan, Mandeh Rubiah telah menganggap Malin Deman sebagai anaknya sendiri. Mandeh Rubiah kerap mengirimkan makanan kepada Malin Deman ketika Malin Deman tengah menjaga tanaman padinya pada malam hari (Djamaris, 2004).

(In the vicinity of Malin Deman's mother's rice field, there lived an old widow. Mandeh Rubiah's name. Malin Deman was very familiar with the old widow. In fact, Mandeh Rubiah has considered Malin Deman as his own son. Mandeh Rubiah often sent food to Malin Deman when Malin Deman was looking after his rice plants at night.)

From the quotes, it shows that in Minangkabau culture the mother figure is closely related to kinship. This point is emphasized also from two other stories that do not show the figure of a mother. In Oheo's story, it is shown that Oheo is an orphan while in the story of the Tujuh Bidadari it is not shown the figure of an old man. The influence of matrilineality in the Kaba Malin Deman story can be seen from the relationship between Malin Deman and Putri Bungsu. 


\section{Symbol of Femininity}

Symbols that mean femininity are related to the tools or objects used by female characters, namely the sarungga-ngguluri in the Anawaingguluri character on the Oheo, the shawl for the youth on the Kaba Malin Deman, and the wings for the Putri Bungsu on the story of the Tujuh Bidadari. In the three folklores, the three female characters who are angels use tools to return to their place of origin. The following is a quote showing the figures of anawaingguluri and sarungga-ngguluri.

Nampaklah olehnya tujuh orang putri dari atas kayangan yang akan turun mandi-mandi. Selain mereka itu, ia juga melihat sedang berjejer sarunngangguruli (sejenis topeng pakaian terbang) di pinggir sungai itu (Arit, 1997).

(He saw seven daughters from above, going down to bathe. Apart from them, he also saw a line of sarunnga-ngguruli (a type of flying clothing mask) on the riverbank.)

From the quote shows thatsarunngangguluri is a object that represents femininity. This case also shows on this quote.

Terperanjatlah Malin Deman ketika melihat tujuh bidadari tengah mandi di kolam yang terletak di belakang pondok Mandeh Rubiah. Malin Deman sangat terpesona melihat kecantikan tujuh bidadari itu ketika wajah mereka terkena sinar rembulan yang tengah purnama. (Djamaris, 2004).

(Malin Deman was stunned when he saw seven angels bathing in the pool located behind Mandeh Rubiah's hut. Malin Deman was very fascinated by the beauty of the seven angels when their faces were hit by the moonlight.)

Likewise with the character of the Youngest Princess with her wings, this is shown in the following quote.

Ketika anak tersebut berumur enam tahun, ia bermain-main dengan abu dekat perapian. Dengan tidak sengaja tangannya menarik suatu benda dari perapian, ternyata benda itu adalah sepasang sayap (Muhamad, 1995).

(When the child was six years old, he played with the ashes by the fire. His hand accidentally pulled an object from the fireplace, it turned out that it was a pair of wings.)

The quotations in the three stories contain two main points, namely (1) showing the femininity of female characters, and (2) technological advances in each culture. The wing is the simplest tool when compared to a scarf or mask. This shows that folklore contains symbols representing the progress of human civilization in a culture.

\section{Symbol of Social Stratification}

The social stratification is shown from the three folklores studied. Symbols are shown from social attributes such as Baginda, Servant, King, Prince, Servant and Angel. Symbols that have the meaning of social class distance are shown in two stories, this is not in the Kaba Malin Deman story because the male characters do not follow the female characters into heaven. The two stories, Oheo and the Tujuh Bidadari, show social class distance through two symbols, namely UeWai and the rattan tree, which are found in the following quote.

Ue-Wai itu mulai tumbuh. Ia tumbuh terus-menerus mengangkasa siang malam (Arit, 1997).

(The Ue-Wai started to grow. It grows steadily taking up the day and night.)

Pohon rotan setuju, mereka segera berangkat. Tepat pukul tujuh pagi, mereka sudah sampai di istana matahari (Muhamad, 1995).

(The rattan tree agreed, they immediately left. At exactly seven in the morning, they arrived at the Sun.)

The two quotes show that there is a social stratification marked by a plant symbol that grows vertically and shows two distinct social classes.

\section{Symbol of Flora and Fauna}

Endemic fauna is a typical animal that characterizes an spesific area. In this case the endemic fauna becomes a symbol to represent a culture. Meanwhile, regional commodities refer to materials produced by the local area. In the three folklores studied, two folklores, namely Oheo and Tujuh Bidadari, show symbols of endemic fauna and regional commodities. The 
following are excerpts from the two stories in question

Bersabda baginda, "Jangan ia langsung naik: masih ada pula satu bakul woto (sejenis tanaman biji seperti sawi) yang akan kalian turunkan dan tuangkan di padang rumput (Arit, 1997).

(Baginda says, "Do not immediately go up: there is also a basket of woto (a type of seed plant such as mustard) which you will bring down and pour in the meadow.)

"Kamu telah lulus syarat yang pertama, sekarang kamu harus menjalani syarat yang kedua. Di sini terdapat dua kendi, satu berisi madu dan satunya lagi berisi minyak kelapa (Muhamad, 1995).

("You have passed the first condition, now you have to fulfill the second condition. Here are two jugs, one filled with honey and one filled with coconut oil.)
The two quotes above show the two characters from the two stories, namely the King and Baginda (the father of the female character) giving challenges to the figures of Oheo and Pangeran Muda. This challenge is not meaningless, if interpreted this challenge is a form of in-law's way of testing their son-in-law in all fields. On the other hand, the use of woto, honey, and coconut oil symbols is a form of cultural identity that shows a distinctive commodity. In addition, the two stories also give a moral message that the animals that appear to help the main character also have functions and benefits.

From the analysis of research, result of cultural symbol in three Nusantara folklores can show in the table 7

Table 7. The Meaning of Cultural Symbol on Nusantara Folklore

\begin{tabular}{llll}
\hline & Oheo & Malin Deman & Tujuh Bidadari \\
\hline $\begin{array}{l}\text { Symbol of femininity } \\
\begin{array}{l}\text { Symbol of flora and } \\
\text { fauna }\end{array}\end{array}$ & $\begin{array}{l}\text { Found on various } \\
\text { challenge }\end{array}$ & Not Found & Wing \\
$\begin{array}{l}\text { Symbol of kinship and } \\
\text { lineages }\end{array}$ & $\begin{array}{l}\text { Found on orphans of } \\
\text { Oheo }\end{array}$ & Widow & Not Found \\
$\begin{array}{l}\text { Symbol of social } \\
\text { stratification }\end{array}$ & Ue-Wai & Not Found & Rattan \\
\hline
\end{tabular}

\section{CONCLUSION}

From the analysis in this study found the results related to the objectives to be achieved. (1) The three Nusantara folklores studied have a varying number of cultural symbols. The Oheo has 12 cultural symbols, the Kaba Malin Deman has 9 cultural symbols, and the Tujuh Bidadari has 13 cultural symbols. 2) The meaning of the symbols found is associated with the seven universal cultural elements. The most prominent meaning in the three stories is cultural identity through character names, endemic fauna, regional commodities, and kinship systems. 3) Comparison of cultural symbols from three folklores refers to the meaning of femininity, endemic fauna and regional commodities, kinship systems, and social stratification.
The contribution of this research for literature and culture are reflected on the result. Symbol and meaning explain that folklore just not a fictitious narrative. But the three Nusantara folklore showed about meaning of culture identity. This research can influence another researcher to more awere abot Nusantara folklore. By studying folklore, Indonesian will think widely from Sabang to Merauke, realize that society has more local wisdom perspective. The research can be used to review the diversity of Indonesia.

\section{ACKNOWLEDGMENT}

Gratitude to Prof. Mudjahirin Thohir, M.A., as a semiotic lecture who help for all 
knowledge, guidance, and direction are given in this research process.

\section{REFFERENCES}

Annisa, A. I. and B. I. (2017). Representasi Sistem Pernikahan Budaya Yogya dalam Novel Perempuan Jogja Karya Achmad Munif. Seloka: Jurnal Pendidikan Bahasa dan Sastra Indonesia, 6(1), 74-94. Retrieved from http://journal.unnes.ac.id/sju/index.php /seloka/article/view/14768

Arit, H. and. (1997). Cerita Rakyat Daerah Sulawesi Tenggara. Jakarta: Direktorat Jenderal Kebudayaan.

Djamaris, E. (2004). Kaba Minangkabau. Jakarta: Pusat Bahasa.

Elfira, M. (2016). The Empress is Back on The Stage: Woman Leadership in Minangkabau Folklore. International Review of Humanities Studies, 1(2), 168179. Retrieved from https://doi.org/10.7454/irhs.v1i2.12

Fallo, J. D. and F. R. (2016). Tuturan Ritual Natoni Adat Masyarakat Etnis Timor dalam Penyambutan Tamu di Sekolah. Seloka: Jurnal Pendidikan Bahasa dan Sastra Indonesia, 5(2), 105-114. Retrieved from http://journal.unnes.ac.id/sju/index.php /seloka/article/view/13070

Hastuti, H. B. P. (2019). Menelusi Tradisi Onggoso Suku Tolaki yang Terepresentasi dalam Mitos Oheo. Aksara, 31(2), 223-238. Retrieved from https://doi.10.29255/aksara.v31i2.433.2 23-238

Hidayah, Z. (2015). Ensiklopedia Suku Bangsa di Indonesia. Jakarta: Yayasan Pustaka Obor Indonesia.

Inayati, T. and N. A. (2016). Symbol dan Makna Pada Puisi Menolak Korupsi Karya Penyair Indonesia. Seloka: Jurnal Pendidikan Bahasa dan Sastra Indonesia, 5(2), 163-171. Retrieved from http://journal.unnes.ac.id/sju/index.php /seloka/article/view/13078
Jauhari, H. (2018). Folklor: Bahan Kajian Ilmu Budaya, Sastra, dan Sejarah. Bandung: Yrama Widya.

Junus, U. (2007). Kebudayaan Minangkabau. Jakarta: Penerbit Djambatan.

Koentjaraningrat. (1990). Pengantar Ilmu Antropologi. Jakarta: Rineka Cipta.

Muhamad, F. (1995). Sastra Lisan Tetun. Jakarta: Pusat Pembinaan dan Pengembangan Bahasa.

Nahak, H. (2019). Upaya Melestarikan Budaya Indonesia di Era Globalisasi. Jurnal Sosiologi Nusantara, 5(1), 65-76. Retrieved from doi://doi.org/10.3369/jsn.5.1.65-76

Nurgiyantoro, B. (2010). Teori Pengkajian Fiksi. Yogyakarta: Universitas Gajah Mada.

Oktavhia, A. P. and B. (2019). Code and Representation of Women in Trans Art Truck Model Roland Barthes Semiotics Studies. Seloka: Jurnal Pendidikan Bahasa dan Sastra Indonesia, 8(2), 14-23. Retrieved from https://journal.unnes.ac.id/sju/index.ph $\mathrm{p} /$ seloka/article/view/30044

Pekuwali, D. S. A., H.B.M, and I.B. (2020). Cultural Meaning of Pahili Mbuala Customary Ritual Speech in Rindi Village, East Sumba Regency: Ethnolinguistic Study. Seloka: Jurnal Pendidikan Bahasa dan Sastra Indonesia, 9(1), 9-17. Retrieved from https://journal.unnes.ac.id/sju/index.ph $\mathrm{p} /$ seloka/article/view/35641

Pradopo, R. D. (1999). Pengkajian Puisi. Yogyakarta: Universitas Gajah Mada.

Ratna, N. K. (2010). Teori, Metode, dan Teknik Penelitian Sastra. Yogyakarta: Pustaka Pelajar.

Rokhmansyah, A. (2014). Studi dan Pengkajian Sastra: Perkenalan Awal Terhadap Ilmu Sastra. Yogyakarta: Graha Ilmu.

Tarimana, A. (1993). Kebudayaan Tolaki. Jakarta: Balai Pustaka. 